\section{THE TRAINING OF THE TEACHER}

BY

\author{
W. R. NIBLETT, B.A., B.Litt. \\ Professor of Education in the University of Leeds
}

At least fifteen thousand teachers are sent newly trained into the schools of the nation every year. Most of them are trained in colleges which offer a two-year course, but teachers who take up posts in secondary grammar schools and an increasing number of those joining the staffs of other types of secondary school are graduates who have had in all a four-year period of training-the first three years being spent at a university in reading for the degree of B.A. or B.Sc. and the year after graduation in a university education department.

During his three years' course the undergraduate will have been fully occupied in his academic studies and will have concentrated upon securing the best degree he can in the subject or subjects of his choice. The postgraduate year of training is therefore a year during which his mind and personality have to be acclimatized to the idea of teaching. It may have been some years since he has even been inside a school, and he is not likely to be very well aware of his own capacity or deficiencies as a teacher of boys or girls.

But the task of a university education department is much wider than that of giving a student various hints and tips about the techniques of teaching in the classroom and of providing chances of practical experience of such teaching. It is true that the total length of the course is quite short. It amounts to about thirty weeks in all, perhaps seventeen of them spent in lectures, discussions, and classes at the university and the remainder in "teaching practice" in schools of various types. In these thirty weeks the student has to be introduced to some of the social, philosophic, and psychological bases of education. All university education departments are anxious that students should not think of the job of teaching simply as one of instructing John and Mary in a particular subject or subjects. The education which a nation gives to its children is an intimate expression of its social and national purpose and character: the children of a nation are its future. It is not merely what they are consciously taught in schools that will matter but the unconscious presuppositions and values which the school as a society will impart to them.

A very important element in the training given to the teacher is his study of the psychological development of children. Such instruction as he receives on the psychology of childhood is no substitute, of course, for personal understanding of children as human beings. But some knowledge of human psychology can undoubtedly deepen understanding of child behaviour and mental growth. A certain number of lectures are given to students upon the physical development of childhood and upon principles of health. There may be lectures, also, upon the history of education in this country, contemporary educational developments in other nations, and the general administration of education

All the lecturers in an education department are themselves teachers of experience, and students take part with them in discussions on teaching methods. During the year the students have experience of trying to teach boys and girls of various ages. This gives them a chance of learning how to co-operate with themselves as teachers, how to shape lessons of many sorts, how to make effective contacts with children of differing temperaments and abilities. During their periods of practice they are encouraged to look upon teaching as an art and a craft calling for great demands not merely upon their knowledge of a subject but upon their human understanding and their skill in interesting an audience and helping it to learn.

\section{Social Factors in Learning}

Clearly there is much in common between the training of a doctor to be a good doctor and a teacher to be a good teacher. It is significant that in these days there should be an increasing emphasis in teacher training upon the importance of social factors in learning, just as there is an increasing emphasis upon social factors in medicine. Similarly, it is realized more and more that the individual child cannot be understood simply as an individual. He must be seen as intimately influenced by the family in which he has been brought up, the social class to which he belongs, his environment of street and newspaper and public opinion. Educational psychology is to be seen as a branch of social psychology. The time allowed for discussions in small groups between students and their lecturers has its counterpart in the case of students training to be doctors.

The training of the teacher, whether in a two-year training college or in a university education department, is not of course to be thought of only as a narrowly professional business. If the student is to make a good teacher he must during the whole time of his training be enriching his humanity. It is important that his capacity for experience should be increased as well as his knowledge of education as a subject and his skill as a practitioner. The experience of students can be stretched in many ways, and use can be made of the arts, the novel, the film, and also of travel. It is important that students training to be teachers should not merely read textbooks upon child development or methods of teaching, but stories about childhood and the childhood parts of various autobiographies. It is very enlightening to them also to read something about education in primitive societies. Such absorbing studies of life in primitive societies as Margaret Mead's Growing $U p$ in New Guinea or Coming of Age in Samoa are valuable books upon education itself.

\section{Institutes of Education}

Since the war, great developments have been taking place in the organization of teacher training in this country. The country has been divided up into regions, each with an institute of education centred upon a university. Henceforward these institutes will be responsible for the training given to teachers within their area. This will inevitably bring about the gradual development of much closer relationships between the two-year training colleges (which in due course will offer three-year courses instead of twoyear) and the universities themselves. The Ministry of Education will in future recognize as qualified teachers only students who have secured a qualification awarded by one or other of the institutes of education.

But institutes, like medical schools, are not concerned only with the initial training of teachers. A very important part of their work will be in " postgraduate" education -in the continued training and education of teachers already in the field. In the past there have been, of course, summer schools, refresher courses, and evening lectures for teachers who cared to attend them. With the coming of institutes of education, however, the scope and provision of such methods of continued training will be much enlarged. 
Post-certificate qualifications for trained teachers are likely to come into existence in considerable numbers. Thus a graduate who has had an initial year of teacher training immediately after receiving his first degree will be able to add to his qualifications as a teacher by taking a more advanced diploma after having taught for some years. This may be general in character or of a specialized sort-e.g., a diploma in primary education, or religious education, or the administration of education. Corresponding qualifications will also be open to those who have qualified as teachers after a period at a two-year training college.

\section{Educational Research}

A third concern of an institute of education is with the organization and encouragement of educational research. Here again there is a parallel with the centres of medical education. In all the five main fields of educational investigation vast territories remain to be discovered-in the sociological, psychological, historical, comparative, and methodological fields. Educational research is not to be regarded simply as a matter of discovering more about actual methods of teaching in the classroom or about more efficient means of examining children at various stages in their school career. We need to know much more than we do about, for example, the educative influence of the cinema, the adaptation of the school curriculum to fit contemporary needs more effectively, the influence of classroom and school design upon the education given within the buildings which have been put up. The curriculum itself in most types of school is what it is for traditional rather than really educational reasons.

Most institutes of education are building up libraries of books available for loan to teachers in their area. They have already begun to publish accounts of experiments and researches which are taking place under their auspices. Indeed, an institute which is really awake will be seeking out and encouraging all sorts of investigations, projects, and new methods within the schools and colleges of its area. It will act as a focus and fertilizing place for vital ideas on many educational matters.

There is an obvious parallel between the work of university institutes of education as they are developing and medical schools which specialize in postgraduate education and advanced medical research. It may be, however, that in institutes of education continued teacher education and the findings of educational research are brought into closer relationship with one another than is sometimes the case in medicine. As time goes on the need is likely to become more apparent for a closer linkage between institutes of education and the departments of medical schools concerned with child health, mental health, and social medicine generally. The doctor in training and the teacher in training have much to give to one another, and so have the staffs engaged in training them.

The Central Council for Health Education held a summer school at the School of Domestic Economy, Eastbourne, from July 28 to August 11 under the direction of the Council's Medical Adviser and Secretary, Dr. Robert Sutherland. This year not only the subjects but the method of study were of interest to both pupils and tutors. The subjects were "The Nature and Needs of Man " and "The Contents, Principles, and Practice of Health Education," and the method of study was that of tutorial group discussion. A short consideration of the theory and method of group discussion completed the course, which was supplemented by the showing of films and a display of health education material and books. The students were drawn from all fields where health education is of importance.

\section{NURSE-TRAINING AND LEGISLATION RETROSPECT AND PROSPECT}

[From a SPecial Correspondent]

When the Nurses' Registration Act was passed in 1919 after long struggles and much controversy it was assumed that the field had been won. The goal on which the nurses had set their hearts was the formal recognition of nursing as a profession. This implied a recognized qualification, and the qualification had been found in State registration. Since that time nurse-training has become more and more a process of obtaining the greatest possible number of passes in the State examinations. Efforts to help other countries to bring their nursing to a higher level have generally included the imposition of a State diploma and of minimum requirements not unlike ours-e.g., a three-year training course. Clichés such as " the one portal of entry," "raising the standard of the profession," "professional selfgovernment of nurses by nurses," have largely dominated the thinking of nurses and have raised a barricade against help which might have come from outside.

Is it possible that the paradoxical situation which exists to-day, when in spite of the steadily mounting numbers of student nurses and pupil midwives entering the training schools since 1938 a grave shortage of nurses and midwives for the hospitals still persists, is due in some measure to a too rigid allegiance to the principle of State registration? To approach the question from another aspect, would anyone claim that the essential art of nursing has made any appreciable progress in the last twenty or thirty years? Has there been any real research into nursing skills, nursing practices-one is tempted to add nursing superstitions? Discounting the effects of modern equipment, modern methods of heating, etc., can the patient entering hospital to-day be sure that the nurses will know better how to ensure his comfort and the well-being of his mind and body than they would have done twenty years ago ? The delicate and elusive art of making the patient comfortable is the very heart and essence of nursing-without it there is no value in all the talk of " raising standards." It may be that some of the "wastage" and restlessness so evident among young nurses is due to frustration-they were groping towards this ideal when they entered hospital and they have found their days ruled by a flurry of ward routines and by the cramming of indigestible "theory" related to the State examination syllabus rather than to the work they are doing in the wards.

The purpose of these notes is to suggest that the maintenance of State registration in its present form has in fact hampered the evolution of nurse-training rather than assisted it. To trace the processes at work we must look further back than the Nurses' Registration Act of 1919, and further afield than the nursing profession.

\section{The Evolution of Nurse-training}

When Miss Nightingale founded a training school for nurses in 1860 with the fund raised in her honour by a grateful nation she sowed the seed for the cultivation of nurse-training schools. Other fine training schools sprang up and made a great name for themselves, but there was one difference-none had the separate endowment and financial independence of the hospital which the Nightingale School had. From 1860 to 1948 the nation made no grants for the training of its nurses. The nurses themselves have largely financed their training by the services they have rendered to the hospitals. It has long been recognized in the hospital 